ROCZNIKI PEDAGOGICZNE

Tom 11(47), numer $4-2019$

DOI: http://dx.doi.org/10.18290/rped.2019.11.4-7

MAGDALENA PARZYSZEK

\title{
SOCIOTHERAPY AS A WAY TO HELP \\ CHILDREN AND YOUNG PEOPLE WITH FUNCTIONAL DISORODERS
}

\section{INTRODUCTION}

Sociotherapy is a form of psychopedagogical help. It is directed, among others, to children and adolescents with psychological and social disorders. It consists in correcting behavioral disorders and selected emotional disorders, and when used in working with children and young people, a sociotherapist can show the person using their support the consequences of the procedure. They become aware of and realize the consequences of difficult behavior, and sociotherapy also teaches them how to cope in various situations.

This article aims to show the essence and significance of sociotherapy as a form of assistance to children and adolescents who exhibit functional disorders and the characteristic therapeutic effects preceded by a diagnosis.

\section{THE CONCEPT OF SOCIOTHERAPY AND ITS GOALS}

The concept of sociotherapy is defined depending on the scientific discipline. It first appeared in psychiatry, where it was understood as "a method that aims to prevent a patient from being isolated from life, and if this has already happened, to bring him back to life, taking into account and using all social agents for this purpose" (Jagieła, 1966, p. 12).

DR. Magdalena ParzyszeK - Department of Family Pedagogy, Institute of Pedagogy, Faculty of Social Sciences at the John Paul II Catholic University of Lublin, Al. Racławickie 14, 20-950 Lublin; e-mail: mparzyszek1@op.pl; ORCID: https://orcid.org/0000-0002-8270-3388. 
Psychotherapists combine this concept with the organization of a social environment that supports the process of treating people with mental health disorders. Therefore, it is included in the scope of environmental therapy (Sawicka, 1999).

The psychological dictionary defines sociotherapy as a form of "therapeutic interaction using the influence of the social environment, the positive impact of a social group and social interaction" (Łosiak, 2009, p. 262).

For pedagogy, sociotherapy is a concept that points to the nature of a disorder. It is one of the ways to alleviate or eliminate negative norms and habits present in social or socially undesirable behavior (Kupisiewicz, Kupisiewicz, 2009, p. 164). Sociotherapy is one of the methods for treating mental disorders involving the use of social types of interactions. Its goal can be the sick person or any social systems that surround them (family, local community), if their dysfunctions trigger, intensify or consolidate the symptoms of the disease. Participating in sociotherapy may consist in expanding one's range of social skills, modifying the surrounding systems, or temporarily or permanently replace learned incorrect interactions with others (Milerski, Śliwierski, 2000).

K. Sawicka sees sociotherapy as a method for treating behavioral disorders and some emotional disorders in children and adolescents during group meetings. Thus, we can treat sociotherapy as a form of psychological help addressed to children and adolescents, an intermediate method between psychotherapy, psycho-education and interpersonal training (Sawicka, 1999, p. 10).

The quoted definitions indicate a slightly different aspect of sociotherapy by referring to the form of the participants' activity, with the possible curative nature, the essence of therapeutic contact, corrective changes, and the nature of the disorder.

Sociotherapy is a form of psychological and pedagogical help addressed to children and youth. It includes therapeutic correction processes of a curative nature that involve the purposeful creation of conditions for children to change their judgments about reality, release their emotions, and acquire new skills in the course of group lessons, which are usually structured and serve to implement educational, developmental and therapeutic goals (Sobolewska, 1993).

The educational goals are to provide knowledge about oneself and other people, and help change behavior, which leads to better functioning in society. It allows a person to recognize emotions, learn about addiction mechanisms, social diseases, to acquire new skills, and learn to resolve conflicts.

The development goals are related to the age of the group's participants and their specific needs, whose satisfaction affects a child's functioning. In early school age children, the most important thing is the need for physical activity, 
playing, the need to acquire knowledge, creativity, support from adults, and the need to be in a peer group in order to undertake joint activities. The period of adolescence is dominated by the need to express oneself in various ways, especially literary, the need for social approval and autonomy, independence and social activity. It is also a time for discovering the mental world and shaping one's views of the world and life (Sawicka, 1999, p. 16). Therefore, the program is structured around issues such as family, helping at home, favorite games, friendship, one's self-presentation and free time.

Therapeutic goals aim to relieve tension and negative emotions and help in learning new skills. The therapeutic approach assumes that difficult behaviors have their own psychological background and may be the result of experiencing violence from adults, emotional rejection by parents, living in a prolonged depriving situation, lack of support in the family, and lack of satisfactory contact with loved ones. It is assumed that they are the result of past or present emotional states that a person could not or cannot cope with. "They are accompanied by unpleasant emotions (fear, guilt, anxiety, hurt, anger, loneliness, etc.) and cognitive judgments about oneself, and more broadly, the attitude towards oneself, other people and the world" (Sawicka, 1999).

Based on the above, several significant elements distinguishing sociotherapy as a method in psychological and pedagogical assistance can be pointed out. These include: the varying ages of class participants, implementing the program in the form of group work, the need to recognize determinants and manifestations of behavioral disorders, and planning corrective actions. Implementing a sociotherapeutic program includes education, therapy and development.

\section{BUILDING THE SOCIOTHERAPEUTIC RELATIONSHIP}

There is no single definition of a therapeutic relationship in the literature on the subject. They are often general, unclear, and very capacious (Gelso, Hayes, 2005). In the psychoanalytic approach, the therapeutic relationship is irreplaceable for effective therapy. Relationships between the therapist and the patient are analyzed (Tonnesmann, 2008). On the other hand, in the existential approach, the therapeutic relationship is the main factor bringing about change, and what is most important in it is being together with another person (Cechnicki, 2000). An attitude full of empathy or unconditional acceptance should characterize a therapist (Gelso, Hayes, 2005). 
Building a sociotherapeutic relationship between the therapist and the client seems challenging. The need for specialized interventions, experience, the different motivations of children and adolescents given this type of activity, the support of relatives and mainly parents, and, above all, a competent diagnosis are just some of the significant requirements for the socio-therapeutic process. For therapy to be effective, several key principles are required. A basic one is the principle of affirmation by keeping the right atmosphere, which means perceiving and emphasizing the positive qualities and abilities of participants and avoiding a critical evaluation of others by indicating vices, pointing to errors or making fun of them. The positive aspirations, achievements and motivations of others are a priority here. The therapist participates in creating the right atmosphere of acceptance and recognition. His behavior is supposed to model such behavior, which becomes a pattern for mutual references (Jagieła, 2007, p. 75).

Another important principle, which is significant for the proper course of the therapeutic process, is the principle of closeness, which means creating warm, safe and close relationships between the teacher and class participants. The therapist is to help class participants attempt to deal with difficulties, to notice everyone, get to know them by name, notice their individuality, be interested in their affairs and problems, and be genuinely interested. Animated exercises are to close the gap among class participants (Jagieła, 2007, p. 76).

The principle of closeness is very closely linked to the principle of openness. Its task is to provide class participants with a way to clearly and openly express things and receive information about themselves. In such an atmosphere, it is possible to reveal important matters, show respect for others' experiences, free themselves from the surrounding isolation, develop boundaries in relations with the environment, acquire the abilities to empathize and solve problems. The role of the sociotherapist here is to express care and sensitivity to the situation when the child reveals their own experiences and remember to keep the fundamental rule regarding confidentiality of contents heard (Jagieła, 2007, p. 77).

The culminating moment in building the right relationship is the principle of the existence of norms for regulating classes, including organizing and structuring their course. They should be understandable to class participants and accepted by them, enabling them to have a good experience. Rules cannot be aimed at participants, but should be an expression of adult kindness and care (Jagieła, 2007, p. 78).

In addition to the norms mentioned above, characteristic of socio-therapeutic relationships, something else is worth recalling: the norm of presence, meaning 
readiness to systematically participate in classes. "In the context of sociotherapeutic activities, this principle is used to diagnose how to be a young person in relation to the group and the person leading it" (Wilk, 2014, p. 174); punctuality is a standard that sets the start and end of activities; a frequency norm that specifies the same day of the week, the same time, and the same meeting room; communication standards defining the participants' attitudes towards each other, not interrupting someone who is speaking and giving feedback; norms prohibiting eating and drinking during classes, talking on the phone or leaving the room; norms codifying contacts with educators, institutions or those conducting classes (Wilk, 2014, pp. 174-175).

As A. Ładyżyński noted, the established therapeutic relationship is a special situation related to helping someone characterized by four dimensions, which are: the therapeutic process, socio-emotional aspects, professionalism and the level of the therapist's openness to the patient (Ladyżyński, 2017, p. 208). The therapeutic process refers to the entire duration of therapy and determining the purpose of the work and its forms. Social and emotional aspects are related to the way of building relationships aimed at engaging and developing an attitude of objectivism in order to establish personal contacts. Professionalism requires keeping the principles, boundaries, respect and a positive attitude towards the patient. Openness towards the patient is manifested by understanding, support, honesty, care and interest on the part of the therapist (Knap, 2009, pp. 20-21).

\section{DIAGNOSIS IN SOCIOTHERAPY}

The term "diagnosis" comes from the Greek word diagnosis, recognition, and means "recognizing an object, event or situation in order to obtain accurate information and prepare for land improvement measures" (Okoń, 1987, p. 52).

According to A. Kamiński, a diagnosis "means diagnosing the examined state of matters based on the collected symptoms and known general regularities by assigning the identified symptoms to a specific type and by a genetic explanation of this state of affairs, determining its current phase and anticipated development" (Kamiński, 1979, p. 50).

The contemporary interpretation of this term emphasizes its two components: the collection of necessary data and their critical compilation when making sense of the matter (Kawula, 1980, p. 44). 
Each previously planned cycle of organized activities consists of a sequence of events: diagnosing the present state, preparing activities, project implementation, and checking the results.

The course of a sociotherapeutic procedure includes the following stages:

1. a preliminary diagnosis, which involves assessing the existing state, creating activities, project implementation and checking the results (Ziemski, 1971). In the case of sociotherapeutic activities, the diagnosis has a subjective nature, because it is related to, for example, traumas, difficult experiences, manifestations of difficult behaviors, and is subjective concerning the relationship with the group and the therapist.

In order to distinguish a disorder from behavior within normal limits in the process of making a diagnosis, M. Pecyna suggests taking into account the following: the child's age, family environment, demands imposed on the child, the rules and norms observed by the parents and passed on to the child, cultural and moral customs prevailing in the child's environment, the child's gender and the resulting differences in the assessment of behavior, the level of tolerance shown by parents and teachers, and the child's individual traits (Pecyna, 1998, p. 30);

2. a full diagnosis, otherwise known as an developed diagnosis, which consists of partial diagnoses, i.e.

- an organizing diagnosis, which consists in assigning a given studied phenomenon to the so-called diagnostic unit, ranking it more or less to a particular type;

- a genetic diagnosis stating the causes of certain states of affairs, for example, peer influence on other students to skip classes;

- a diagnosis of meaning (purposefulness) - defines the significance of the existing state of affairs for an individual's overall functioning (e.g. how a certain type of behavior disorder affects functioning at school);

- a phase diagnosis determining the level of severity (e.g. the degree of behavioral disturbance);

- a prognostic diagnosis aimed at determining how a given state of affairs can or should change in a given time perspective (e.g. what will the child's further functioning be like after completing sociotherapy) (Jagieła, 2007, p. 68 ).

B. Jankowiak and E. Soroko propose a multidimensional view of diagnosis in sociotherapy. They draw attention to:

1. a diagnosis qualifying a person for sociotherapeutic assistance; 
2. diagnosing a participant's psychological situation, carried out in a descriptive manner and at an explanatory level;

3. diagnosing group processes taking into account the interpersonal functioning of participants;

4. an evaluation of assistance procedures at the group and individual levels (Jankowiak, Soroko, 2014).

Regardless of which approach we prefer to undertake in a sociotherapeutic diagnosis, our goal is to gather the most thorough information that would allow us to develop a program to correct the types of disorders in children and adolescents and initiate the therapeutic process.

\section{WORKING IN THE AREA OF BEHAVIOR AND UPBRINGING}

The literature on the subject lacks uniform terminology that would allow us to clearly define what "behavioral disorders" are. They are often equated with social maladjustment or difficulties with discipline.

According to J. Konopnicki, behavioral disorders are deviations from the norm, which should be understood as moral principles, customs and habits adopted in a given environment. Such disorders are, for example, learning difficulties, but also neurosis or crime. They are proof of the changes that must have taken place in a child's psyche and are also the result of an imbalance between the environment and organism (J. Konopnicki, 1964).

M. B. Pecyna claims that when "calling something a disorder, or abnormal behavior, one can include any adverse deviations from the normal development of the child's body and psyche, and define them as covering all types of childhood difficulties" (Pecyna, 1998, p. 195).

In the case of children and adolescents, behavioral disorders are associated with: excessive aggression directed towards people or animals, increased quarreling with peers and adults, physical and mental violence, getting into fights, being a tyrannt in one's environment, theft, burglary, arson, extortion, destruction of someone's property, lies, constant disobedience, running away from home, risky sexual behavior, skipping classes (Sulestrowska, 1989, p. 118).

Three types of behavioral disorders can be found in the literature on the subject: behavioral disorders manifesting themselves only in a family context, of a non-socialized character, and of a socialized nature (Gindrich, 2007). 
Behavioral disorders manifesting themselves in the family context are extremely important. It is in the family that the child learns how to respond to events and people, and thus learns about the outside world. It is here that he or she acquires the skills necessary to correctly solve difficulties and achieve intended goals. However, families may not function properly. This abnormality can be expressed by:

1. insufficiently fulfilling basic tasks related to child care;

2. lack of strong emotional ties among family members, emotional separation or a family isolating themselves from other people;

3. excessive symbiosis among family members, mutual dependence;

4. overprotecting the child, which on the one hand can be an expression of a fearful attitude, and on the other can be a mask, meaning rejecting the child;

5. a three-fold communication type of disorder:

a) everyone in the family must know everything about everyone else;

b) there is a lack of information flow, especially regarding emotional experiences;

c) so-called double bonding verbal messages, which are contrary to nonverbal messages;

6. an erosion of the parent-child relationship;

7. a pathology in the family roles;

8. family resistance to conflict disclosure (Popielarska, 1989).

Behavioral disorders that manifest themselves only in a family context are characterized by dissocial or aggressive reactions, abnormal behaviors that arise completely or almost completely in the family home and concern interactions among family members.

Unsocialized disorders are associated with abnormal peer relationships, meaning a child's failure to integrate with the peer group resulting in their isolation from the group, rejection by the group, and consequently lack of friends. The child's relationships with adults are characterized by quarrels, hostility, disagreement, and any agreeable relationships with adults, which are possible in this case, are characterized by a lack of closeness and trust.

The last group consists of socializing disorders that affect reactions characterized by dissociality or aggressiveness, which appear in people who are well integrated into the peer group. The main feature is the presence of proper, lasting, and friendly relationships with others. Often, however, the group the child integrates into consists of persons committing criminal acts. 


\section{WORKING IN THE AREA OF EMOTIONS}

Defining emotions presents certain difficulties. Some people characterize emotions as structures that control life, especially our relationships with other people (Oatley, Jenkins, 2003) or as subjectively experienced states that reflect our attitude to our needs and the surrounding reality (Woynarowska, 2007).

Emotions are mental states that cause physiological, somatic, cognitive and behavioral changes (Doliński, 2000). They define human relationships with the environment, help us adapt to the world around us, influence the direction of our activity and the processes of cognition and learning (Levenson, 1998).

As J. Wilsz noticed, emotions are regulated through external interactions and internal self-regulation mechanisms. Therefore, they fulfill the functions of:

- steering, because they steer human internal processes and through man control the environment;

- regulatory, affecting human reactions / behaviors, and through them affect the environment;

- motivational, because they favor the start of reactions or resist their happening;

- selective, they limit negative information for a person and beneficial information is supported;

- engaging, because they urge a person to take actions favorable for them and discourage them from undertaking harmful actions;

- adaptive, because they signal when changes are necessary for disturbances in one's functional balance to be reduced, or even for someone to reach the state of functional balance;

- connected with satisfying needs, because they favor undertaking activities that meet one's needs;

- interpersonal, because they affect the course of the communication process (Wilsz, 2009, pp. 93-111).

The period of adolescence is characterized by significant emotional changes, starting with the intensity of experienced feelings and behaviors to so-called emotional instability, or ambivalence of feelings.

Socio-therapeutic work in this area should be aimed at teaching children and adolescents how to cope with difficult situations, making a rational assessment of reality and building self-esteem, meaning gradual step-by-step maturing. As E. Wysocka notes, an individual's maturity [...] is always the result of the interaction of two immanently related developmental processes: the process of 
maturation (rather passive) and the process of learning (rather active) (Wysocka, 2003, p. 723).

Looking at the issue of socio-therapeutic work in the field of emotions, one should notice the process of shaping such maturity. It is determined by the following criteria: the adequacy of reactions, ways of communicating, controlling and recognizing emotions (Ostrowska, 1999, p. 56). This is done by:

- emotional control manifested in the ability to control emotions and express them in a manner adequate to the situation;

- emotional stability;

- the ability to deal with emotions in difficult situations, during crisis moments;

- the acceptance of so-called difficult feelings;

- accepting one's own weaknesses;

- emotional diversity related to the ability to experience qualitatively different emotions (Strus, 2009, p. 72).

\section{WORKING ON CORRECTING ONE'S IMAGE}

In the literature on the subject, one's self-image is captured as an "organized set of traits which the individual has learned to recognize as their own, based on previous and current experience, integrating their personality structure and repetition of sets of behavior patterns" (Siek, 1984, p. 276).

It is made up of three basic groups of elements:

- the descriptive element: the self-concept or self-knowledge;

- a value element: a set of self-evaluations, the feeling of self-esteem;

- the normative element: the ideal self (Brzezińska, 1973, p. 91).

Understanding the areas that are relevant to creating an image of yourself is important for making a diagnosis and formulating problems related with inadequate functioning or dissatisfaction with yourself. An inadequate self-image manifests itself in the areas of functioning that determine adaptation (I-adults, I-peers, I-task situations, I-I).

Disturbed behavior in contacts with adults is mainly associated with communication difficulties. This can be manifested, for example, in lies, aggression, selfclosure, bad behavior, and entering into conflicts. In this case, during sociotherapeutic classes, correction should include interpersonal skills such as: the ability to express needs, abandoning aggressive patterns of self-expression, communicating 
one's emotional states, the ability to show and accept criticism, taking advantage of support.

Peer relationships are an important element of the child's socialization process. They allow one to assimilate the rules prevailing in a group and in society. They can shape a child's behavior thanks to positive and negative reinforcements of specific behaviors. Lack of acceptance in the group, experiencing humiliation, fear, disregard, physical and psychological violence, rivalry, keeping one's distance and isolation, or verbal aggression may hinder contact with peers. The goals outlined in the sociotherapeutic program should include developing the skills of interacting with others, resolving conflicts without violence, negotiating, actively listening to each other, presenting positive information about others, and expressing one's judgments.

Self-assessment and self-acceptance are of great importance for a person's proper functioning. Self-esteem is shaped throughout a lifetime under the influence of one's own experience as well as the judgments by society. It can be understated when a person does not believe in his strengths and real possibilities, or it can be overstated when an individual claims that he is able to do things that he cannot objectively cope with (Kulas, 1986, p. 17). People with overstated selfesteem endure stress-related situations much easier; moreover, self-acceptance results in positive interpersonal relationships due to the acceptance of others (Muszyńska, 2001, pp. 132-133).

Self-acceptance, meaning a lasting attitude towards yourself, is characterized by faith, trust and a healthy attitude towards yourself, feeling proud about yourself, perceiving yourself in a favorable way, at the same time being aware of your strengths and weaknesses, and the ability of self-irony indicate the degree to which an individual is self-satisfied and convinced that she or he achieves goals and meets the requirements they consider to be important. Self-acceptance is conducive to building self-esteem and self-efficacy (Pilecka, 1999, p. 24).

A child with an inadequate self-image in difficult situations can use defense strategies, modifying cognitive judgments in such a way that they eliminate the unpleasant state of tension. They can attribute themselves inadequate features, underestimate their own abilities, depreciate their appearance or personality traits, become an easy target for all types of abuse, have difficulties in building lasting relationships with others, and manifest susceptibility to any sort of influence.

Sociotherapeutic classes should aim to change behavior, correct one's selfperception to the best of our abilities, teach the ability to focus on oneself, the ability to recognize one's emotional states, identify one's needs, determine one's 
resources and good character traits, receive feedback about oneself, organize and plan one's tasks, set stages for achieving goals, master organizational skills and structure knowledge.

\section{CONCLUSION}

Children and young people who are said to exhibit behavioral disorders must be surrounded by the proper care of parents, educators, teachers and therapists.

Considering the issue of sociotherapy as a way to help children and young people who exhibit dysfunctions, it is worth emphasizing its important role in the upbringing process. The perception of changes taking place in young people under the influence of sociotherapeutic interactions takes on a positive value when this form of support is used consciously, systematically and willingly to make changes. The effects of interactions depend to a large extent on the attitude of the person subject to sociotherapeutic influences, as well as thanks to the person of the therapist who is concerned about the effects of actions undertaken in the field of behavior and upbringing in terms of emotions and self-image correction.

\section{Translated by Jan Kobytecki}

\section{BIBLIOGRAPHY}

CECHNICKI, A. (2000). Co jest istotne w psychospołecznym leczeniu schizofrenii [Essentials in Psychosocial Therapy of Schizophrenia]. In: J. BomBA (ed.), Schizofrenia, różne konteksty, różne terapie [Schitzophrenia, Different Contexts, Different Therapies] (p. 37-47). Kraków: Biblioteka Psychiatrii Polskiej.

Gelso, J.C., Hayes J.A. (2005). Relacja terapeutyczna [The Therapeutic Relationship]. Gdańsk: GWP.

GindRICH, P. (2007). Psychospoleczne komponenty nieprzystosowania [Psychosocial Components of Maladjustment]. Lublin: Wydawnictwo UMCS.

DoliśSKI, D. (2000). Mechanizmy wzbudzania emocji [Mechanisms for Building Emotions]. In: J. Strelau (ed.), Psychologia. Podręcznik akademicki [Psychology. Academic Textbook]. Vol. 2. (pp. 383-392). Gdańsk: Wydawnictwo Psychologiczne.

JAGIEŁA, J. (1966). Analiza roli socjoterapii we wspótczesnej psychiatrii [An Analysing of Sociotherapy in Contemporary Psychiatry]. Warsaw: Wydawnictwo: Adam Marszałek.

JaGIEŁA, J. (2007). Socjoterapia w szkole. Krótki poradnik psychologiczny [Sociotherapy in School. A Brief Psychologcial Guide]. Kraków: Rubikon. 
JANKOWIAK, B. (2013). Socjoterapia jako forma pomocy psychologiczno-pedagogicznej. Teoria i praktyka [Sociotherapy as a Form of Psychological and Pedagogical Assistance]. Poznań: Wydawnictwo Naukowe UAM.

JANKOWIAK, B., SOROKO, E. (2014). Style socjoterapeutycznej pracy grupowej z dziećmi i młodzieżą z perspektywy czynników pomocowych [Sociotherapeutic Styles for Group Work with Children and Adolescents from the Perspective of Aid Factors]. Studia Edukacyjne, 31, pp. 195218.

KAWULA, S. (1980). Istota i zakres diagnostyki pedagogicznej środowiska [The Essence and Scope of Environmental Pedagogical Diagnostics]. In: S. Kawula, Z. DĄBRowski, M. GaŁaś (ed.), Diagnozowanie potrzeb opiekuńczo-wychowawczych i kulturalnych środowiska [Diagnosing the Care, Upbringing and Cultural Needs of the Environment] (pp. 40-80). Torun: Uniwersytet Mikołaja Kopernika.

KnAP, H. (2009). Komunikacja w terapii [Communication in Therapy]. Warsaw: PWN.

KonopNicki, J (1964). Powodzenia i niepowodzenia szkolne [Success and Failure in School]. Warsaw: PZWS.

Kulas, H. (1986). Samoocena młodzieży [Adolencent Self-Evaluation]. Warsaw: WSiP.

Kupisiewicz, Cz. Kupisiewicz, M. (2009). Stownik pedagogiczny [A Pedagogical Dictionary]. Warsaw: Wydawnictwo Naukowe PWN.

LEVENSON, R.W. (1998). Funkcjonalne podejście do ludzkich emocji [A Functional Approach to Human Emotions]. In: P. EKMAN, R.J. DAWIDSON (ed.), Natura emocji [The Nature of Emotions] (pp. 112-115). Gdańsk: GWP.

ŁADYŻYŃSKI, A. (2017). Terapia jako forma pomocy rodzinie w powrocie do równowagi [Therapy as a Way to Aid a Family in Regaining Equilibrium]. In: M. PARZYSZEK, M. SAMOraŃSKa (ed.), Rodzina wsparcie i pomoc [The Family, Support and Aid] (pp. 205-212). Lublin: Episteme.

ŁosIAK, W. (2009). Socjoterapia [Sociotherapy]. In: J. SiUTA (ed), Stownik psychologii [Pedagogical Dictionary] (p. 262). Kraków: Krakowskie Wydawnictwo Naukowe.

Milerski, B., Śliwierski, B. (2000). Pedagogika. Leksykon [Pedagogy. Lexicon]. Warsaw: PWN.

MuszYŃSKA, E. (2005). Ogólne problemy wychowania w rodzinie dzieci niepełnosprawnych [General Problems in Upbringing Disabled Children in a Family]. In: I. OBUCHOwsKA (ed.), Dziecko niepetnosprawne w rodzinie [A Disabled Child in the Family] (pp. 101-164). Warsaw: WSiP.

OATLEY, K., JenKIns, J. (2003). Zrozumieć emocje [Understanding Emotions]. Warsaw: PWN.

Ostrowska, K. (1999). Dojrzałość [Maturity]. In: D. LalaK, T. PILch (ed.), Elementarne pojęcia pedagogiki spolecznej i pracy socjalnej [Elementary Concepts of Social Pedagogy and Social Work] (pp. 56-58). Warsaw: Wydawnictwo Akademickie Żak.

PECYNA, M.B. (1998). Rodzinne uwarunkowania dziecka w świetle psychologii klinicznej [A Child's Family Conditions in the Light of Clinical Psychology]. Warsaw: WSiP.

Pecyna, M.B. (1999). Psychologia kliniczna w praktyce pedagogicznej [Clinical Psychology in Pedagogical Practice]. Warsaw: Wydawnictwo Akademickie Żak.

PILECKA, W. (1999). Choroba przewlekła w życiu i rozwoju dziecka [Chronic Disease in a Child's Life and Development]. In: W. PileckA, P. Majewicz, A. ZawadZKi (ed.), Jak wspomagać psychospoleczny rozwój dzieci niepelnosprawnych somatycznie [How to Support the Psychological Development of Somatically Disabled Children] (pp. 7-36). Kraków: Wydawnictwo Edukacyjne.

PopielarsKA, A. (1989). Etiologia i patogeneza zaburzeń psychicznych u dzieci [Etiology and Pathogenesis of Psychic Disturbances in Children]. In: A. PopielarsKa, M. PopielarsKa (ed.), Psychiatria wieku rozwojowego [Psychiatry in the Developmental Years]. Warsaw: PZWL.

SAwICKA, K. (1999). Socjoterapia [Sociotherapy]. Warsaw: Wydawnictwo Seventh Sea. 
SAWICKA, K. (1999). Współczesne tendencje w systemie opieki nad dziećmi, Problemy Opiekuńczo-Wychowawcze [Contemporary Tendencies in the Child Caretaking System, Caretaking and Upbringing Problems], 5, 336-342.

SoBolewSKA, Z. (1993). Zajęcia socjoterapeutyczne dla dzieci i młodzieży - zasady projektowania zajęć [Sociotherapeutic Activities for Children and Adolescents]. Warsaw: OPTA.

Strus, W. (2009). Podstawowe właściwości dojrzałości emocjonalnej [Basic Traits of Emotional Maturity]. In: K. FrANCZAK, M. SzPRINGER (ed.), Oblicza dojrzałości emocjonalnej dzieci $i$ mlodzieży [The Face of Emotional Maturity in Children and Youth] (pp. 61-88). Warsaw: Wydawnictwo Salezjańskie.

SulEstrowsKA, H. (1989). Zaburzenia zachowania u dzieci i młodzieży [Behavioral Disorders in Children and Adolescents]. In: A. Popielarska., M. Popielarska (ed.), Psychiatria wieku rozwojowego [Psychiatry for the Developmental Years]. Warsaw: PZWL.

TONNESMANN, M. (2008). Przeniesienie $i$ przeciwprzeniesienie [Transferring and Countertransferring]. In: S. BUDD, R. RUSBRIDGER (ed.), Wspótczesna psychoanaliza brytyjska [Contemporary British Psychoanalysis] (pp. 231-249). Warsaw: Oficyna Ingenium.

WiLK, M. (2014). Diagnoza w socjoterapii [Diagnosis in Psychotherapy]. Sopot: Wydawnictwo GWP.

WILSZ, J. (2009). Teoria pracy [Work Theory]. Kraków: Impuls.

WOYNAROWSKA B. (2007). Edukacja zdrowotna [Health Education]. Warsaw: PWN.

WysockA, E. (2003). Dojrzałość szkolna [School Maturity]. In: T. PILCH (ed.), Encyklopedia pedagogiczna XXI wieku [21 $1^{\text {st }}$-Century Pedagogical Encyclopedia] (pp. 722-729). Warsaw: Wydawnictwo Akademickie Żak.

ZIEMSKI, S. (1971). Cykl działania zorganizowanego a diagnoza. Prakseologia [The Cycle of Organized Activity and the Diagnosis. Praxiology], 39-40.

\section{SOCJOTERAPIA JAKO FORMA POMOCY DZIECIOM I MŁODZIEŻY PRZEJAWIAJĄCYM ZABURZENIA W FUNKCJONOWANIU}

Streszczenie

Wczesne dostrzeżenie zaburzeń w funkcjonowaniu dzieci i młodzieży oraz próba motywowania do zmian są nie lada wyzwaniem dla rodziców czy nauczycieli.

W niniejszym artykule przedstawione zostało ogólne spojrzenie na socjoterapię jako pewnego rodzaju pomoc psychologiczną „w obszarze oświaty i instytucji opiekuńczo-wychowawczych, ukierunkowaną na dzieci i młodzież z grup ryzyka i/lub przejawiające zaburzenia w funkcjonowaniu psychospołecznym, która polega na intencjonalnym uruchamianiu czynników pomocowych, wykorzystujących procesy grupowe w celu kompensacji potencjalnych deficytów rozwoju psychospołecznego uczestników grupy" (Jankowiak, 2013, s. 49-50). Zostały zaprezentowane treści dotyczące interdyscyplinarnego rozumienia pojęcia socjoterapii, jej celów, budowania relacji socjoterapeutycznej, diagnozy oraz pracy w zakresie zachowania i wychowania, emocji oraz korygowania obrazu własnej osoby.

Słowa kluczowe: socjoterapia; cele edukacyjne; cele terapeutyczne; cele rozwojowe; relacja socjoterapeutyczna; diagnoza; zachowanie; wychowanie; emocje; obraz własnej osoby. 


\section{SOCIOTHERAPY AS A WAY TO HELP CHILDREN AND YOUNG PEOPLE WITH FUNCTIONAL DISORDERS}

\section{S u m m a ry}

Early recognition of disorders in the behavior of children and teenagers as well as attempts to motivate them to change is a challenge for parents and teachers. In this article, a general view of sociotheraphy as a kind of psychological assistance will be presented "in the field of education and care-educational institutions, targeted at children and adolescents at risk and manifesting disorders in psychosocial functioning, which is based on intentional activation of help factors, using group processes to compensate for potential deficits in the psychosocial development of group participants" (Jankowiak, 2013, pp. 49-50). The contents of our interdisciplinary understanding of the sociotherapy concept will be presented in the article, as well as its goals, building a sociotherapeutic relationship, diagnosis and work in the field of behavior and upbringing, emotions and correcting one's personal self-image.

Key words: sociotheraphy; educational goals; therapeutic goals; developmental goals; sociotherapeutic relationship; diagnosis; behaviour; upbringing; emotions; self-image. 